\title{
Schinus terebinthifolius Raddi: Scientometric Analysis
}

\author{
Schinus terebinthifolius Raddi: Análise Cientométrica \\ Schinus terebinthifolius Raddi: Análisis Cienciométrico
}

Received: 06/09/2021 | Reviewed: 06/17/2021 | Accept: 06/22/2021 | Published: 07/07/2021

\author{
Christiane França Martins \\ ORCID: https://orcid.org/0000-0002-8177-0458 \\ Universidade Federal de Goiás, Brazil \\ E-mail: franh.chris@gmail.com \\ Walmyr Alberto Costa Santos Junior \\ ORCID: https://orcid.org/0000-0002-3340-1658 \\ Universidade Federal do Amapá, Brazil \\ E-mail:walmyrj@@gmail.com \\ Liliane de Sousa Silva \\ ORCID: https://orcid.org/0000-0001-9497-7573 \\ Universidade Federal de Goiás, Brazil \\ E-mail: ssliliane@gmail.com \\ José Realino de Paula \\ ORCID: https://orcid org/0000-0002-4424-7692 \\ Universidade Federal de Goiás, Brazil \\ E-mail: pjrpaula@gmail.com
}

\begin{abstract}
Schinus terebinthifolius (Anacardiaceae) is among the medicinal species native to Brazil, known as mastic-red and mastic-pepper, whose stem bark is used to fight inflammation of various origins, as it has anti-inflammatory and healing properties. The objective of this study is to explore trends in the publications portrayed on the species $S$. terebinthifolius, analyzing axes such as time, countries, journals, impact factors and citations, the scientometric approach was used to summarize all the studies on $S$. terebinthifolius in a single article. 475 publications were used with an average number of 20.8 publications per year, encompassing 68 research areas and published in 220 different journals, covering all retractions visible on the Web of Science from 2001 until May 2021. The most productive country was Brazil with 271 articles, followed by the USA with 105 articles. The methods and results of this study can be applied to continually understand the nature of research on the species.
\end{abstract}

Keywords: Anacardiaceae; Scientometry; Medicinal plant; Brazilian peppertree.

\section{Resumo}

Schinus terebinthifolius (Anacardiaceae) está entre as espécies medicinais nativas do Brasil, conhecidas como mástique-vermelha e mástique-pimenta, cuja casca do caule é utilizada no combate a inflamações de várias origens, pois possui propriedades antiinflamatórias e cicatrizantes. O objetivo deste estudo é explorar tendências nas publicações retratadas sobre a espécie $S$. terebinthifolius, analisando eixos como tempo, países, periódicos, fatores de impacto e citações, a abordagem cienciométrica foi utilizada para resumir os estudos sobre S. terebinthifolius em um único artigo. Foram utilizadas 475 publicações com número médio de 20,8 publicações por ano, abrangendo 68 áreas de pesquisa e publicadas em 220 periódicos diferentes, abrangendo todas as publicações disponíveis na Web of Science de 2001 até maio de 2021. O país mais produtivo foi o Brasil com 271 artigos, seguido por os EUA com 105 artigos. Os métodos e resultados deste estudo podem ser aplicados para compreender continuamente a natureza da pesquisa sobre as espécies.

Palavras-chave: Anacardiaceae; Cienciometria; Planta medicinal; Pimenta brasileira.

\section{Resumen}

Schinus terebinthifolius (Anacardiaceae) se encuentra entre las especies medicinales nativas de Brasil, conocidas como masilla-roja y masilla-pimiento, cuya corteza del tallo se utiliza para combatir la inflamación de diversos orígenes, ya que tiene propiedades antiinflamatorias y curativas. El objetivo de este estudio es explorar tendencias en las publicaciones retratadas sobre la especie Schinus terebinthifolius, analizando ejes como tiempo, países, revistas, factores de impacto y citas, se utilizó el enfoque cienciométrico para resumir todos los estudios sobre Schinus terebinthifolius en un artículo. Se utilizaron 475 publicaciones con un promedio de 20,8 publicaciones por año, abarcando 68 áreas de investigación y publicadas en 220 revistas diferentes, cubriendo todas las retracciones visibles en la Web of Science desde 2001 hasta mayo de 2021. El país más productivo fue Brasil con 271 artículos, seguido de EE.UU. con 105 artículos. Los métodos y resultados de este estudio se pueden aplicar para comprender continuamente la naturaleza de la investigación sobre la espécie.

Palabras clave: Anacardiaceae; Cienciometría; Planta medicinal; Peppertree brasileño. 


\section{Introduction}

The species of the Anacardiaceae family are marked by having great economic importance in the supply of edible fruits, useful woods or ornamental species (Wheeler et al., 2016), and are known to contain a great diversity of attractive biomolecules (Feriani et al., 2021). The healing potential of many medicinal species is due to the bioactive compounds produced by the secondary metabolism of these plants (Zotti-Sperotto et al., 2021). Several species of medicinal plants are popularly used to combat different types of diseases. However, since they are products that have not yet been studied, medicinal plants need a lot of research, which has provided important advances in the treatment of various pathologies (Azevedo et al., 2015).

Schinus terebinthifolius Raddi, is one of the new potent botanical agents in the prevention and treatment of chronic diseases (Feriani et al., 2021), it has been used as a remedy for ulcers, respiratory problems, wounds, rheumatism, gout, tumors, diarrhea, skin ailments, arthritis, antiseptic, balsamic, haemostatic, anti-inflammatory and antimicrobial. Also, the decoction of flowers, stalks, fruits and leaves are used for the treatment of tumors and lepra (Lima et al., 2009; Santana et al., 2012; Tlili et al., 2018). Its biological applications have been described since the first edition of the Brazilian Pharmacopoeia, published in 1926. Is known as "pimenta-rosa", "aroeira-vermelha", "aroeira-pimenteira", "aroeira-da-praia", "aroeira-negra" and/or "aroeira-de-minas" (Silva et al., 2017), mainly for the appearance of its fruits and for being used as a food flavoring. In addition to its medicinal properties, this vegetable is commonly used in the afforestation of streets and squares and in the production of firewood and charcoal (Azevedo et al., 2015).

The species, which has a tropical and subtropical distribution, is native to South America, encompassing Brazil, Paraguay, Uruguay and eastern Argentina. and can be found in Europe, where it is cultivated as an ornamental species, Central and South America, mainly in Florida, where it has an invasive behavior. It is widely distributed throughout the Brazilian territory, extending from Pernambuco to Rio Grande do Sul (Wheeler et al., 2016). Due to the ease of adaptation to different habitats, the species can survive in dry seasons, it is easily seen throughout the coast of Brazil, but also in dry lands, inhabiting various plant formations.

In the Florida Everglades ecosystem, Brazilian Peppertree is the most widely distributed and abundant invasive weed, occupying 30,379 ha - an area greater than the combined infestations of the next 3 most-problematic plant species. The US Fish and Wildlife Service (1998) identified Brazilian Peppertree as one of the most significant nonindigenous species currently impacting federally listed threatened and endangered native plants throughout the Hawaiian Islands. Initial surveys to search for potential biological control agents for Brazilian Peppertree were conducted in northern Argentina and Brazil in the 1950s and early 1960s. Classical biological control may provide an ecologically sound, cost-effective, and sustainable component of management strategies to protect native plants in these habitats (Wheeler et al., 2016).

The objective of the present work, therefore, was to carry out a scientometric analysis of publications on the species $S$. terebinthifolius, in the Web of Science database, to evaluate the development of scientific researches with the species published so far. Thus, the number of articles published on the subject, authors, journals, countries, institutions, citations and co-citations, the most identified words in the main research areas addressed, was quantified. After data collection, the VOSviewer software was used to generate, visualize and analyze bibliometric networks. It is hoped that the results of this research will provide researchers and practitioners with a comprehensive understanding of the status quo, trend research and promote further study in this field. 


\section{Methodology}

\subsection{Database collection}

One of the decisions to make in undertaking an analysis of a knowledge domain such as in this study is for the researcher(s) to identify scientific databases to use. The primary sources of databases were The Clarivate Analytics Web of Science (WoS) (Olawumi et al., 2018). The WoS has been widely recognized as an important database by the international scientific community (Castro et al., 2021) and covers journals, and being able to exclude articles of conference proceedings, meeting abstracts, editorial materials, and reviews. The database was used to search for scientific studies on Schinus terebinthifolius (updated in May 2021). The keywords "Schinus" AND "terebinthifolius" for the topic search, showing results since 1977, we restrict the search of the information on period 2001 to 2021, and we exclude articles of conference proceedings, meeting abstracts, editorial materials, and reviews (Figure 1).

\subsubsection{Data analysis}

Scientometrics is defined as the quantitative study of science (Kim \& Chen, 2015), is a technique that allows for a broader yet concise capturing and mapping of a scientific knowledge area by identifying structural patterns and tracing salient research frontiers using mathematical formulae and visualization (Olawumi \& Chan, 2018). The scientometric analysis is a technology that demonstrates the scientific development process and structure relationship based on the knowledge domain (Si et al., 2019). For scientometric analysis, this study used VOSviewer, which is a software tool designed for constructing and viewing bibliometric maps, networks with journals, researchers, or individual publications as authors, and based on co-citation, bibliographic coupling, or co-authorship relations, useful for displaying large bibliometric maps in an easy-to-interpret way. Once the data is obtained, the analysis develops a performance analysis process (Van Eck \& Waltman, 2010; Moral-Muñoz et al., 2020).

Five scientometric techniques would be adopted in this study: (i) Year of publication, (ii) Research area/and journals, (iii) Countries/regions and institutions contributions (iv) Authors citation (v) Articles more citated and Network analysis. The data have been submitted to statistical analysis with the aid of the Microsoft Excel. Those analyses can help follow-up researchers to understand the research trends of $S$. terebinthifolius field in the recent years. Citation analysis can be carried out using five different units of analysis in bibliometric analysis such as document, sources, authors, countries, and institution of affiliation.

Figure 1. Outline of research design.

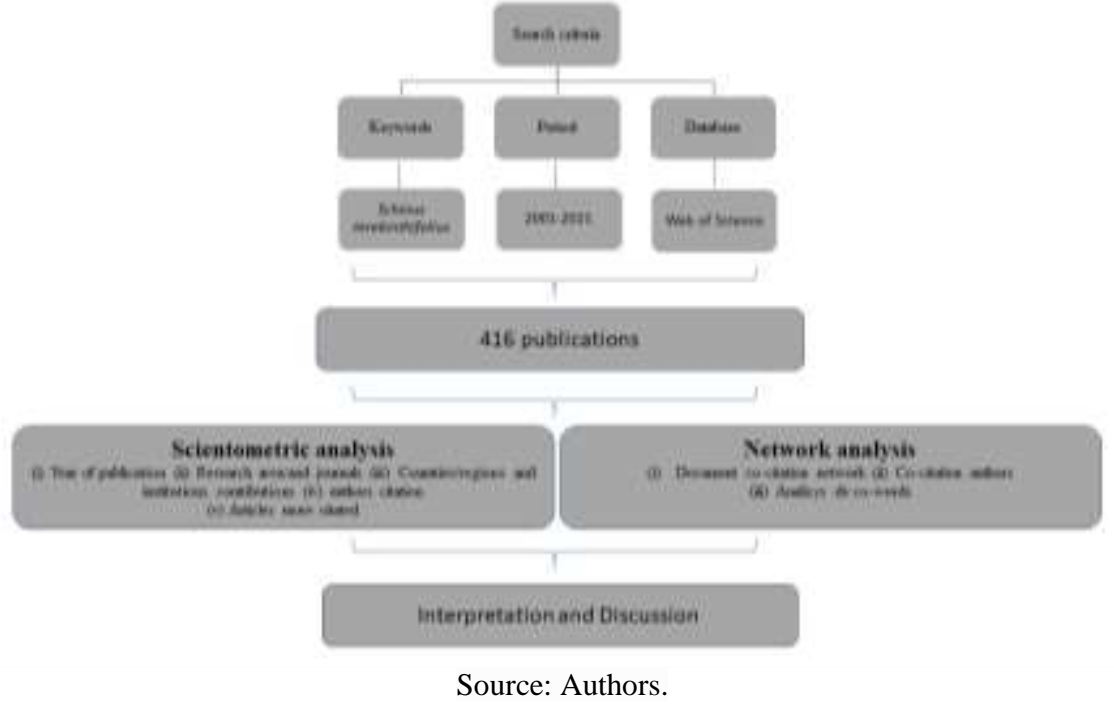




\section{Results and Discussion}

This section discusses the facets and results of the scientometric analysis of this study, as described in the research project. The study digitized journal article titles and abstracts to identify valuable articles in the researched field.

\subsection{Scientometric analysis}

\subsubsection{Articles Published}

This procedure collected a total of 475 articles in different journals classified in all WoS categories. To limit the range of articles, this study selected only 416 journal articles that met all the criteria, omitting 41 articles from conference proceedings, meeting abstracts, editorial materials, and reviews. These articles were cited 5527 times cited in article publications as references. From 2001 to 2021, the distribution of annual publications is shown in Figure 2.

Figure 2. The growth of publications, 2001-2021. The panel shows the number of study accessions published according to sample size, to show the growth of publications over time.

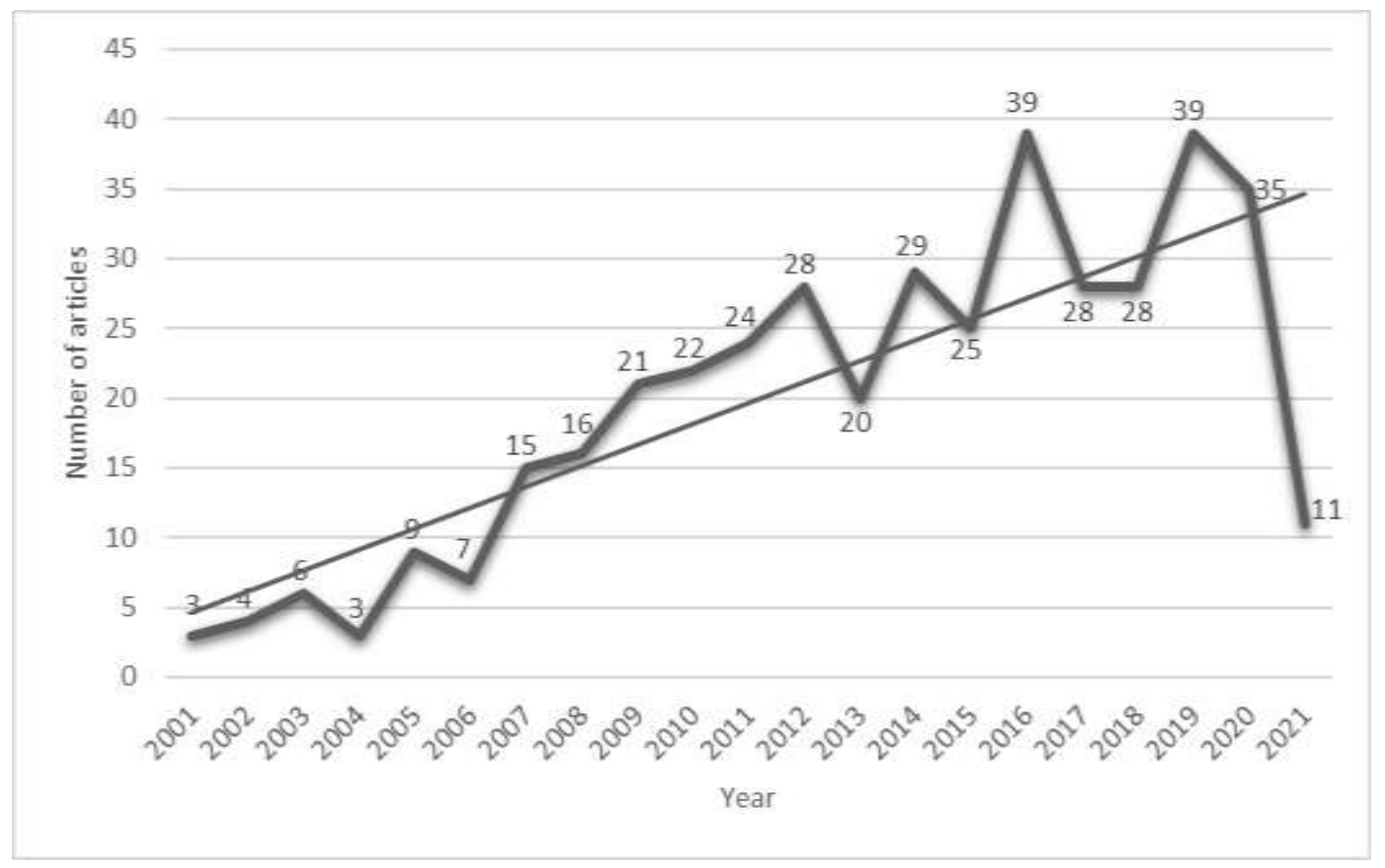

Source: Authors.

The first article on S. terebinthifolius was in 1977 with a focus on terpenes registered in the plant (Lloyd, 1977), between 1997 and 2007 less than 10 articles were published each year, revealing that this field of research was in a preliminary stage. In general, the results have been increasing continuously for almost 20 years, the number of articles increased after 2007 , maintaining the average number of 20.8 publications per year, which has not reached a high level, suggesting that this field still needs attention and advances important. The trend line follows the exponential distribution, showing slow growth during the early years and more growth in later years. In 2021, only 11 articles were found, however, as we are in May, the expectation is to reach the same number or more publications as the trend line is projected. In general, even though the year 2021 shows a dip, the annual publication trend follows an increasing trend. 


\subsubsection{Research area/and journals}

The research areas discussed in this section refer to the most cited research areas and journals of S. terebinthifolius as defined by WoS. The 416 articles were categorized into 68 research areas and (Figure 3) and the articles selected published in 220 different journals.

Figure 3. Number of publications in the top ten research area from 2001 to 2021.

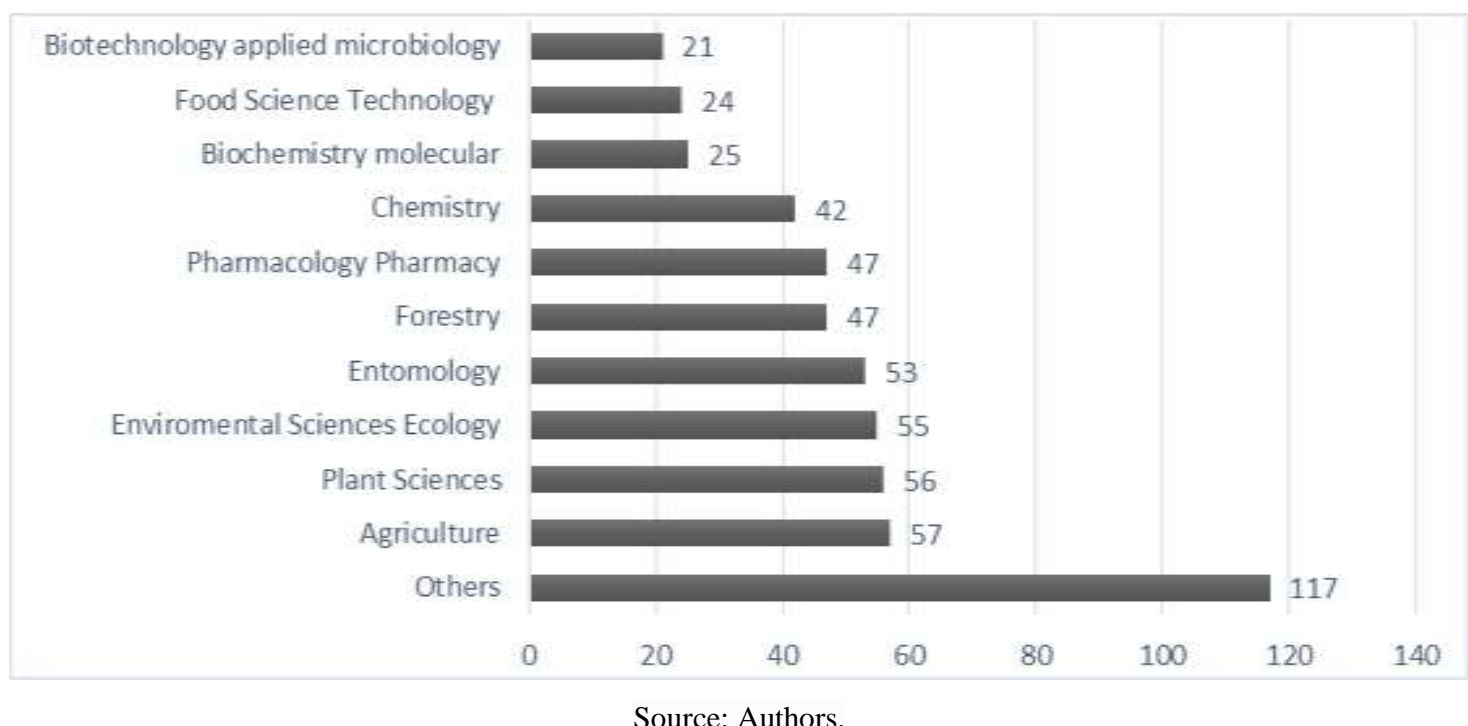

Figure 3 shows the most common research area was Agriculture, and 57 articles were categorized in this area, which is equivalent to $13.6 \%$ of the total number of articles. Interestingly, two other areas have the same frequency as Plant Sciences and Environmental Science Ecology, with 56 articles (13.3\%) and 55 articles (13.1\%) respectively. The next most was Entomology with 53 articles (12.9\%), Forestry and Pharmacology Pharmacy both with 47 articles (11.2\%), Chemistry with 42 articles (10\%). The last three most common areas in the study are Molecular Biochemistry, Food Science Technology, Biotechnology Applied Microbiology all with less than six percent and other distinct areas with 117 articles, which all these areas indicated is the diversity of this research field.

The top 20 journals accounted for approximately $65 \%$ of the 416 publications. The top 5 most productive journals that have published at least 10 articles of S. terebinthifolius from 2001 to 2021 on Table 1.

Table 1. Journals with highest number of papers in this field.

\begin{tabular}{c|ccc} 
source & documents & citations & total link strength \\
\hline Brazilian Journal of Pharmacognosy & 13 & 209 & 470 \\
Biocontrol Science and Technology & 11 & 56 & 1204 \\
Biological Invasions & 11 & 331 & 435 \\
Ciência Rural & 10 & 54 & 102 \\
Revista Árvore & 10 & 36 & 68 \\
total & 55 & 686 & 2279
\end{tabular}


Table 1 represents the most productive journals, Brazilian Journal of Pharmacognosy were tied for first place (13 articles followed by Biocontrol Science and Technology (11 articles), Biological Invasions (11 articles) and Ciência Rural and Revista Árvore both with 10 articles. These top three journals accounted for $13 \%$ of the total articles, which might indicate that they were the most influential publications in the field for the past twenty years. As can be seen from the research area and journal list, the study of $S$. terebinthifolius involves multiple disciplines. The table also shows the number of citations and total link strength of each journal.

\subsubsection{Countries/regions and institutions contributions}

According to the present study, researchers from 42 countries published articles on S. terebinthifolius between 2001 to 2021 frow the WoS. Researchers from Brazil are responsible for more 65\% (271 articles), followed by USA $25 \%$ (105 articles), Egypt 4\% (19 articles), France 3\% (14 articles), Argentina 3\% (13 articles). These results showed the advanced research and development in science study in these countries about this plant.

Figure 4. Shows the contribution network of countries/regions of knowledge Schinus terebinthifolius, which includes 10 clusters and 332 links. The size of the node represents the research contribution or number of publications all made major contributions to the research on from 2001 to 2021.

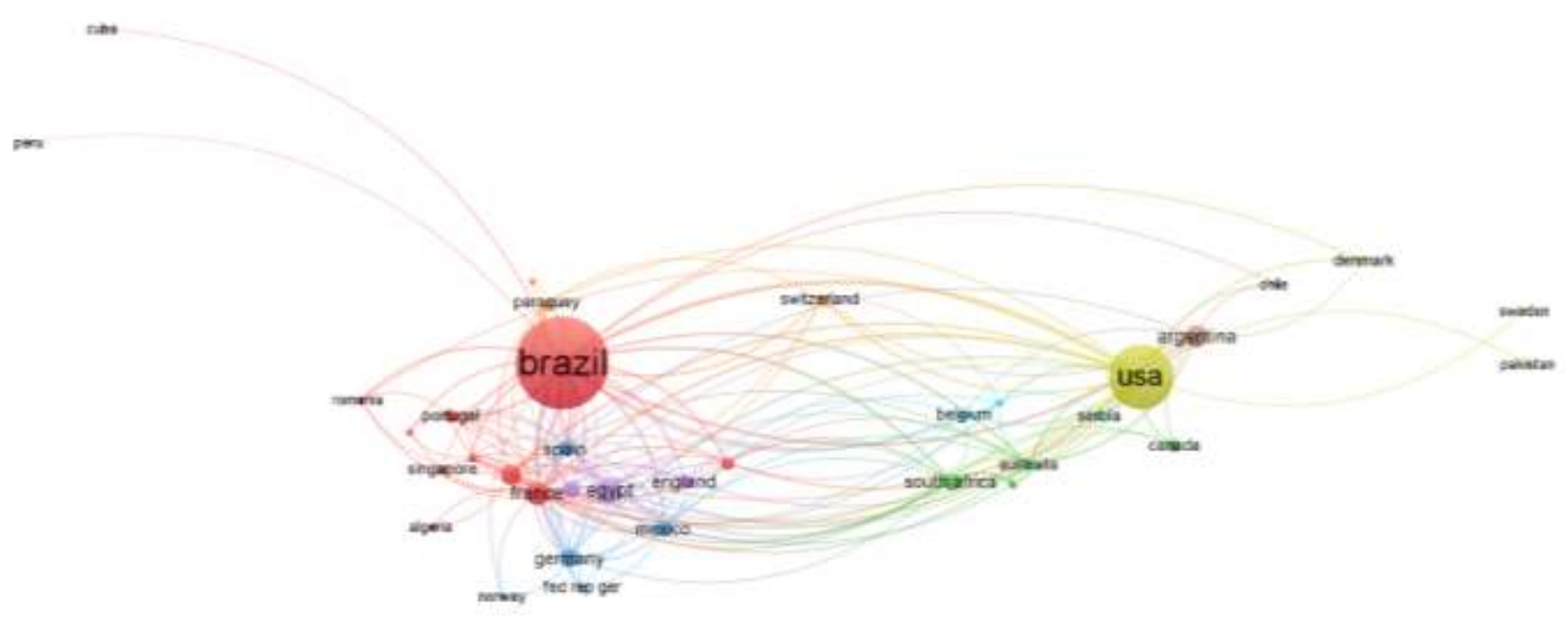

Source: Authors.

As shown in Figure 4, cluster represent the contributing countries, lines mean the cooperation of countries, and 10 clusters and 332 links in the partner countries formed a network. The size of the node corresponds to the significance of countries toward study, the number of links between any two countries represents the strength of collaboration, while the color intensity is proportional to the number of publications.

The reason why USA is second responsible for the most published is because historical records indicate it was intentionally introduced twice into Florida as an ornamental plant from South America in the late 1800 `s, between 1898 and 1900, and is now widespread in the state as far north as Jacksonville (Prade et al., 2021; Nickerson \& Flory, 2015; Williams et al., 2007). However, Brazilian peppertree began invading the Everglades National Park after a 50-60 years lag period and today is considered one of the most aggressive invasive upland species in Florida (Prade et al., 2021), exerting devastating ecological and economic impacts in the area (Dawkins \& Esiobu, 2018) and has been also recorded in Alabama, California, Georgia, Hawaii, and Texas (Prade et al., 2021) Given the ecological and economic impacts of biological invasions there is a 
pressing need to understand the mechanisms underlying invasive species impacts on native communities. The impacts of invasions may bedriven by competition, alteration of habitat conditions, allelopathy, or other mechanisms (Mukherjee et al., 2012).

In addition, contributions in terms of research institutions have progressed significantly at several universities. Institutions with the highest number of papers, among which are the State University System of Florida, USA (43 articles), the United States Department of Agriculture USDA (39 articles), the University of Florida, USA (30 articles), Federal University of Viçosa, Brazil (27 articles), University of São Paulo, Brazil (24 articles); Federal University of Paraná (21 articles); Federal University of Pernambuco (18 articles), Federal Rural University of Rio de Janeiro, Brazil (16 articles), Federal University of Grande Dourados, Brazil (15 articles). In addition, we have the Paulista State University, the Federal University of Espírito Santo and the Federal Rural University of Pernambuco, Brazil (14 articles).

\subsubsection{Authors contribution}

The 416 publications shortlisted from the WoS database involve contributions from 1704 authors and coauthors. The contribution of the individual author and collaborative authors has been analyzed in this domain, the five most productive authors are described below (Table 2).

Table 2. Top five most productive authors.

Author

\begin{tabular}{l|cc}
\hline Wheeler, Gregory S. & United States Department of Agriculture (USDA) & 22 \\
Cuda, James P. & University of Florida & 19 \\
Overholt ,W.A. & University of Florida & 16 \\
Williams, D.A. & Texas Christian University & 9 \\
Manrique, V. & Southern University System & \\
& Source: Authors.
\end{tabular}

Institution

\begin{tabular}{l|cc}
\hline Wheeler, Gregory S. & United States Department of Agriculture (USDA) & 22 \\
Cuda, James P. & University of Florida & 19 \\
Overholt ,W.A. & University of Florida & 16 \\
Williams, D.A. & Texas Christian University & 9 \\
Manrique, V. & Southern University System & \\
& Source: Authors.
\end{tabular}

\section{Number of Articles}

Table 2 shows an analysis of the most productive authors reveals Wheeler G. S (United States Department of Agriculture (USDA), Cuda, J.P (University of Florida) and Overholt (University of Florida), Williams D. A (Texas Christian University) Manrique, Veronica (Southern University System) as the five researchers with most publications in the field and work in partnership with the not control biological of the US species.

\subsubsection{Articles more citated}

The most-cited articles on the topic of S. terebinthifolius since 2001 were summarized in Table 3 with 10 most cited articles, including total citations, year published as well as a research direction. It should be pointed out that the research directions were not necessarily mutually exclusive. 
Table 3. Top 10 most cited articles.

\begin{tabular}{|c|c|c|c|}
\hline Authors & Title & Citations & Year \\
\hline Bendaoud et al. & $\begin{array}{l}\text { Chemical composition and anticancer and antioxidant activities of Schinus molle } \\
\text { 1. and Schinus terebinthifolius Raddi berries essential oils }\end{array}$ & 129 & 2010 \\
\hline Dong et al. & $\begin{array}{l}\text { Mechanistic investigation of mercury sorption by Brazilian pepper biochars of } \\
\text { different pyrolytic temperatures based on x-ray photoelectron spectroscopy and } \\
\text { flow calorimetry }\end{array}$ & 122 & 2013 \\
\hline $\begin{array}{l}\text { Schmourlo et } \\
\text { al. }\end{array}$ & $\begin{array}{l}\text { Screening of antifungal agents using ethanol precipitation and bioautography of } \\
\text { medicinal and food plants }\end{array}$ & 121 & 2005 \\
\hline Williams et al. & $\begin{array}{l}\text { Chloroplast and microsatellite DNA diversities reveal the introduction history of } \\
\text { Brazilian peppertree (Schinus terebinthifolius) in Florida }\end{array}$ & 108 & 2005 \\
\hline Lamarque et al. & $\begin{array}{l}\text { Tree invasions: a comparative test of the dominant hypotheses and functional } \\
\text { traits }\end{array}$ & 94 & 2011 \\
\hline Lima et al. & Anti-bacterial activity of some Brazilian medicinal plants & 74 & 2006 \\
\hline $\begin{array}{c}\text { Morgan \& } \\
\text { Overholt }\end{array}$ & $\begin{array}{l}\text { Potential allelopathic effects of Brazilian pepper (Schinus terebinthifolius Raddi, } \\
\text { Anacardiaceae) aqueous extract on germination and growth of selected Florida } \\
\text { native plants }\end{array}$ & 74 & 2005 \\
\hline Barbosa et al. & $\begin{array}{l}\text { Seasonal variation in the composition of volatile oils from Schinus } \\
\text { terebinthifolius Raddi }\end{array}$ & 65 & 2007 \\
\hline $\begin{array}{l}\text { Badawy \& } \\
\text { Abdelgaleil }\end{array}$ & $\begin{array}{l}\text { Composition and antimicrobial activity of essential oils isolated from Egyptian } \\
\text { plants against plant pathogenic bacteria and fungi }\end{array}$ & 63 & 2014 \\
\hline Ewe et al. & Seasonal plant water uptake patterns in the saline southeast Everglades ecotone & 62 & 2007 \\
\hline
\end{tabular}

Citation records from WoS records reveal that 10 cited documents received sixty or more citations. The most cited article is an article by Bendaoud et al. (2010), with 129 citations with an average of 10.75 citations per year published in the Journal of Food Science with studies on the chemical composition and anticancer and antioxidant activities of Schinus molle L. and Schinus terebinthifolius Raddi essential oils from berries, the second most cited article is by Dong et al. (2013), with 122 citations with an average of 13.56 citations per year, published in the Journal Environmental Science \& Technology and studies on the mechanistic investigation of sorption mercury by Brazilian pepper biochars from different pyrolytic temperatures based on X-ray photoelectron spectroscopy and flow calorimetry, while the third most popular article is by Schmourlo et al. (2005), with 121 citations with an average of 7.12 annual citations published in the Journal of Ethnopharmacology which studies the screening of antifungals by ethanol precipitation and bioautography of medicinal plants and food.

\section{Network analysis}

\subsection{Document co-citation network}

Co-citation analysis of bibliographic elements contained in the scientific literature can be applied to explore the knowledge structure and dynamic evolution of a specific research area. Co-citation analysis was a useful method to map how subject specialties of scientific research and to study how differences in research between sets of publications. (Wei \& Zang, 2020). In the study, our clustering technique determines the relatedness of publications based on direct citation relations, the analysis of co-citation of documents based on the documents of each author evaluates the references cited by the 5864 bibliographic records with an average of 290 citations per year to understand the intellectual structures of the species in the field of plant knowledge. 
Figure 5. Shows the contribution documents co-citation network of knowledge Schinus terebinthifolius, which includes 15 clusters and 307 links. The size of the node represents the research contribution or number of citations all made major contributions to the research on from 2001 to 2021.

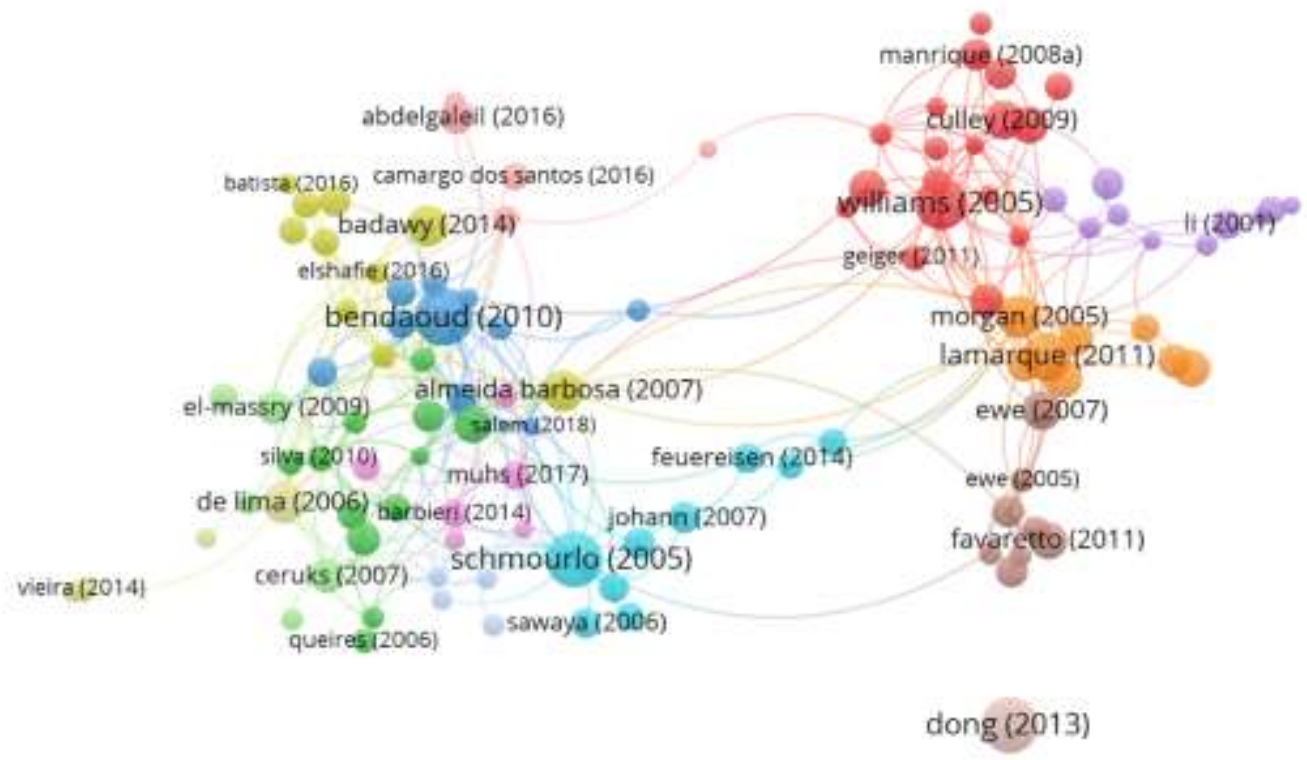

Source: Authors.

Figure 5 represents the 127 main documents co-cited articles in the reference or bibliography of selected articles with a limit of 15 citations per document. In the co-citation map, fifteen well-defined clusters are observed. The co-citation network shows a network of references that have been co-cited by a number of publications. Each node represents a cited reference, and the borders denote the co-cited relationships between articles (Wei \& Zhang, 2020). VOSviewer colors groups of citations using a set of colors selected from the menu on the right. The largest clusters are colored dark red for the largest, green for the second largest, dark blue for the third largest, and yellow for the fourth largest cluster (Williams, 2020). Highly cited articles are indicated by the larger size of the bubble (Lazar \& Chithra, 2021).

\subsection{Co-citation authors}

A co-citation link is built by the authors who are citing the articles (Figure 5). Once two articles are cited together in another article results in the co-citation of the two articles, say, in this case, authors, documents, or journals are cited by a journal article and described as a "proximity measure" for the items (Lazar \& Chithra 2021; Olawumi, 2018). Co-citation analysis of authors offered a new technique that could contribute to understanding the intellectual structure of the sciences (Wei \& Zhang, 2020). A visualization of the 215 authors e 4 clusters and their citation relations is provided in Figure 6. 
Figure 6. Shows the contribution network of authors of knowledge Schinus terebinthifolius, which includes 4 clusters and 6307 links. The size of the node represents the research contribution or number of publications all made major contributions to the research on from 2001 to 2021.

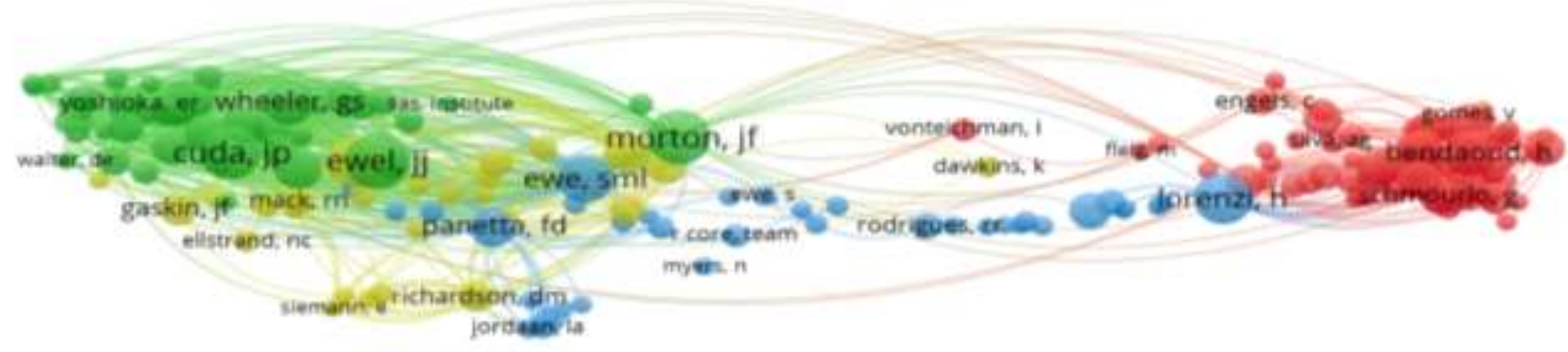

Source: Authors.

In the co-citation analysis, Figure 6, seven well-defined clusters are observed. VOSviewer colors clusters of citations using a set of colors selected using the menu on the right hand side. The largest clusters are colored with a dark red for the largest, green for the second largest, a dark blue for the third largest and yellow for the fourth largest cluster (Williams, 2020).

In this visualization, the size of a cluster reflects the number of publications belonging to the cluster. Larger clusters include more publications. The distance between two clusters approximately indicates the relatedness of the clusters in terms of citations. Clusters that are located close to each other tend to be strongly related in terms of citations, while clusters that are located further away from each other tend to be less strongly related. The curved lines between the clusters also reflect the relatedness of clusters, with the thickness of a line representing the number of citations between two clusters (Van Eck and Waltman, 2010).

\subsection{Analysis de co-words}

The mapping of the most used keywords and terms helps researchers to define the types of research in their searches and studies (Van Eck \& Waltman, 2010). This analysis supports research to select the correct search terms, we identified the 41 keywords with a minimum threshold of 8 occurrences each is shown in Figure 7. 
Figure 7. Shows keywords most used of knowledge Schinus terebinthifolius, which includes 3 clusters and 288 links. The size of the node represents the research contribution or number words used all made major contributions to the research on from 2001 to 2021.

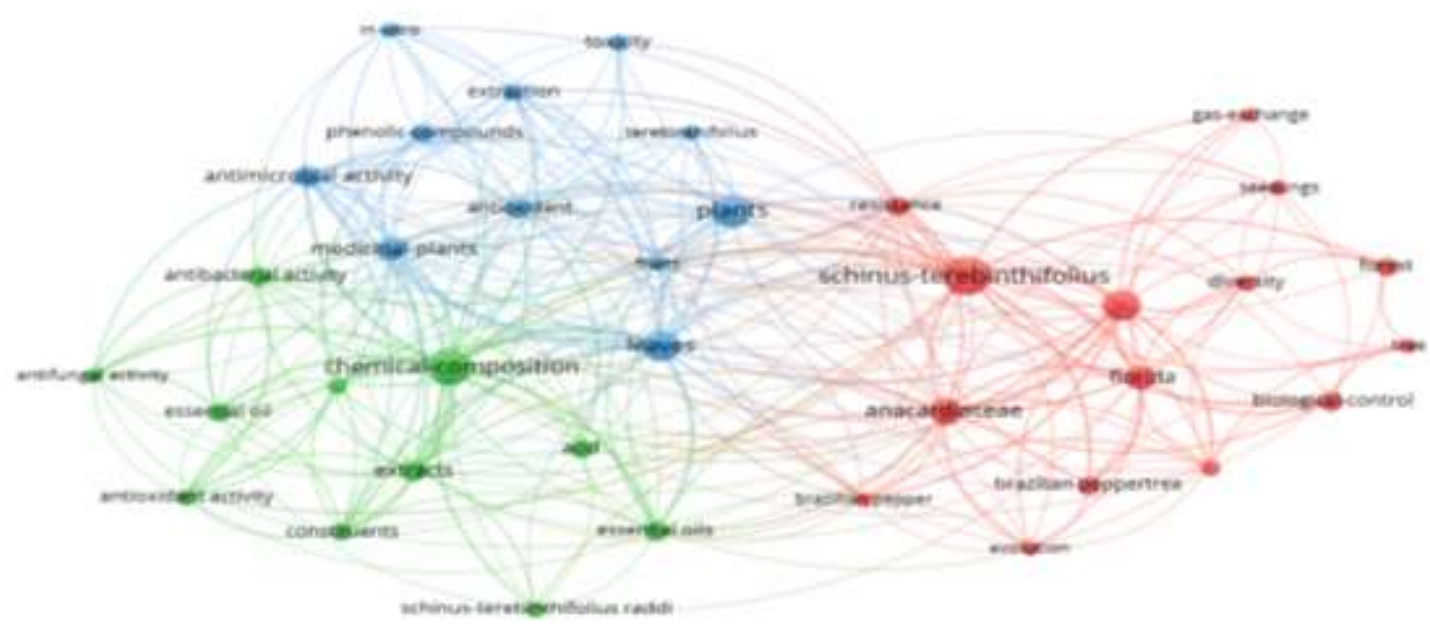

Source: Authors.

Figure 7 shows the 41 most used keywords in the study documents. The colors represent the division of clusters between the words, each one representing a cluster. The three clusters are interconnected, forming a total of 288 links between the keywords. The most frequent words are Schinus terebinthifolius (56 occurrences), with 30 links, chemical composition (48 occurrences) 26 links, plants (38 occurrences) 23 links, each word is the most important of each cluster visualized, red, green and blue, respectively.

Analyzing the clusters, we observe that the words used in each cluster are linked to a specific area of research. The grouping of the red cluster is formed by words linked to biological control, the growth of Brazilian pepper in Florida. The green cluster group is formed by words linked to the biological activities and chemical composition of the extract and essential oil. The blue cluster grouping is linked to the study of plant toxicity.

\section{Conclusion}

In this study, we have performed a comprehensive study of the worldwide scientific output of Schinus terebinthifolius Raddi research from 2001 to May 2021. showing that scientific production on the species has been growing, thus standing out the importance of the subject. This scientometric study provides an in-depth analysis of the species' global survey, highlighting the multidisciplinary nature. Over the past two decades, research has progressed enormously, resulting in a better understanding in the areas of agriculture, plant studies, ecology, chemistry and pharmacology.

National and international collaboration plays an important role in research in this area. Greater international cooperation could help in the study and concentration of research activities in countries with more developed scientific systems, such as Brazil or the United States, and increase knowledge reaching more areas of less explored research. With regard to this, the objective of the current research work was to collect, record, and illustrate the possibility and extent of the current research and serve as a source for future consultations on the topic, identifying the most recent research trends that could help significantly the increase the traditional literature reviews and provide helpful information to determine new research directions and perspectives. 


\section{Acknowledgments}

The authors thank the anonymous reviewer for the comments, which helped us improve the manuscript. This study received financial support from the Brazilian Coordenação de Aperfeiçoamento de Pessoal de Nivel Superior (CAPES) and Conselho Nacional de Desenvolvimento Científico e Tecnológico (CNPq, National Council for Scientific and Technological Development), and Fundação de Amparo à Pesquisa do Estado de Goiás (FAPEG).

\section{References}

Azevedo, C. F., Quirino, Z. G. M., \& Bruno, R. L. A. (2015). Estudo farmacobotânico de partes aéreas vegetativas de aroeira-vermelha (Schinus terebinthifolius Raddi, Anacardiaceae). Revista Brasileira De Plantas Medicinais, 17(1), 26-35.

Barbosa, L. C. A., Demuner, A. J., Clemente, A. D., Paula, V. F., \& Ismail, F. M. D. (2007). Seasonal variation in the composition of volatile oils from Schinus terebinthifolius raddi. Química Nova, 30(8), 1959-1965.

Badawy, M. E. I., \& Abdelgaleil, S. A.M. (2014). Composition and antimicrobial activity of essential oils isolated from Egyptian plants against plant pathogenic bacteria and fungi. Industrial Crops and Products, 52, 776-782.

Bendaoud, H., Romdhane, M.. Souchard, J. P, Cazaux, S., \& Bouajila J. (2010). Chemical composition and anticancer and antioxidant activities of Schinus Molle L. and Schinus Terebinthifolius Raddi berries essential oils. Journal of Food Science, 75 (6), 0-0.

Castro, M. S., Barbosa, F. G., Guimarães, P. S., Martinez, C., Martins, G. \& Zanette, J. (2021). A scientometric analysis of ecotoxicological studies with the herbicide atrazine and microalgae and cyanobacteria as test organisms. Environmental Science and Pollution Research-Springer, $28,25196-25206$.

Dawkins, K. \& Esiobu, N. (2018). The invasive Brazilian Pepper tree (Schinus terebinthifolius) is colonized by a root microbiome enriched with alphaproteobacteria and unclassified spartobacteria. Frontiers in Microbiology, 9, 876.

Dong, X., Ma, L. Q., Zhu, Y., Li, Y., \& Gu, B. (2013). Mechanistic investigation of mercury sorption by Brazilian Pepper biochars of different pyrolytic temperatures based on X-ray photoelectron spectroscopy and flow calorimetry. Environmental Science \& Technology, 47(21), $12156-12164$.

Ewe, S. M. L., Sternberg, L. d. S. L. \& Childers, D. L. (2007). Seasonal plant water uptake patterns in the saline southeast Everglades ecotone. Oecologia, $152,607-616$.

Feriani, A., Tir, M., Arafah, M., Gómez-Caravaca, A. M., Contreras, M. d. M., Nahdi, S., Taamalli, A., Allagui, M. S., Alwasel, S., Segura-Carretero, A., Harrath, A., \& Tlili, N. (2021). Schinus terebinthifolius fruits intake ameliorates metabolic disorders, inflammation, oxidative stress, and related vascular dysfunction, in atherogenic diet-induced obese rats. Insight of their chemical characterization using HPLC-ESI-QTOF-MS/MS. Journal of Ethnopharmacology, 269, 113701.

Kim, M. C. \& Chen, C. (2015). A scientometric review of emerging trends and new developments in recommendation systems. Scientometrics - Springer, $104,239-263$.

Lamarque, L. J., Delzon, S., \& Lortie, C. J.(2011). Tree invasions: a comparative test of the dominant hypotheses and functional traits. Biological Invasions Springer, 13, 1969-1989.

Lazar, N. \& Chithra, K. (2021). Comprehensive bibliometric mapping of publication trends in the development of building sustainability assessment systems. Environment, Development and Sustainability, 23, 4899-4923.

Lima, L. B., Vasconcelos, C. F. B., Maranhão, H. M. L., Leite, V. R., Ferreira, P. A., Andrade, B. A., Araújo, E. L., Xavier, H. S., Lafayette, S. S. L., \& Wanderley, A. G. (2009) Acute and subacute toxicity of Schinus terebinthifolius bark extract. Journal of Ethnopharmacology, $126,468-473$.

Lima, M. R. F., Ximenes, E. C.P., Azevedo, Luna, J. S., \& Sant'Ana, A. E. G. (2006). The antibiotic activity of some Brazilian medicinal plants. Revista Brasileira de Farmacognosia, 16(3), 300-306.

Lloyd, H. A., Jaouni, T. M., Evans, S. L., \& Morton, J. F. (1977). Terpenes of Schinus terebinthifolius. Phytochemistry, 16, 1301-1302.

Olawumi, T. O. \& Chan, D. W. M. (2018) A scientometric review of global research on sustainability and sustainable development. Journal of Cleaner Production, 183, 231-250.

Olawumi, T. O., Chan, D. W. M., Wong, J. K. W, \& Chana, A. P. C. (2018). Barriers to the integration of BIM and sustainability practices in construction projects: A Delphi survey of international experts. Journal of Building Engineering, 20, 60-71.

Moral-Muñoz, J. A., Herrera-Viedma, E., Santisteban-Espejo, A., \& Cobo, M. J. (2020). Software tools for conducting bibliometric analysis in science: An upto-date review. El Profesional de la Información, 29(1), 1699-2407.

Morgan, E. C., \& Overholt, W. A. (2005). Potential allelopathic effects of Brazilian Pepper (Schinus terebinthifolius Raddi, Anacardiaceae) aqueous extract on germination and growth of selected Florida native plants. The Journal of the Torrey Botanical Society, 132, 11-15.

Mukherje, A., Williams, D. A., · Wheeler, G. S., Cuda, J. P., Pal, S., \& Overholt, W. A. (2012). Brazilian peppertree (Schinus terebinthifolius) in Florida and South America: evidence of a possible niche shift driven by hybridization. Biological Invasions, 14, 1415-1430.

Nickerson, K. \& Flory, L. (2015). Competitive and allelopathic effects of the invasive shrub Schinus terebinthifolius (Brazilian Peppertree). Biological Invasions, 17, 555-564. 
Prade, P., Minteer, C. R., Gezan, S. A., Arguijo, V. C., Bowers, K., Cuda, J. P., \& Overholt, W. A. (2021). Host specificity and non-target longevity of Calophya lutea and Calophya terebinthifolii, two potential biological control agents of Brazilian Peppertree in Florida, USA. Biological Control, 66, $281-294$.

Santana, J. S., Sartorelli, P., Guadagnin, R. 1 C., Matsuo, A. L., Figueiredo, C. R., Soares, M. G., Silva, A. M., \& Lago, J. H. G. (2012). Essential oils from Schinus terebinthifolius leaves - chemical composition and in vitro cytotoxicity evaluation. Pharmaceutical Biology, 50(10), $1248-1253$.

Schmourlo, G., Mendonça-Filho, R. R., Alviano, C. S., \& Costa, S. S. (2005). Screening of antifungal agents using ethanol precipitation and bioautography of medicinal and food plants. Journal of Ethnopharmacology, 96(3), 0-568.

Silva, M. M., Iriguchi, E. K. K., Kassuya, C. A. L., Vieira, M. C., Foglio, M. A, Carvalho, J. E., Ruiz, A. L. T.G, Souza, K. P, \& Formagio, A. S. N. (2017). Schinus terebinthifolius: phenolic constituents and in vitro antioxidant, antiproliferative and in vivo anti-inflammatory activities. Revista Brasileira de Farmacognosia, 27, 445-452.

Tlili, N., Yahiab, Y., Ferianic, A., Labidid, A., Ghazouanic, L., Nasria, N., Saadaouid, E., \& Khaldid, A. (2018). Schinus terebinthifolius vs Schinus molle: A comparative study of the effect of species and location on the phytochemical content of fruits. Industrial Crops \& Products, 122, 559-565.

Van Eck, N. J. \& Waltman, L. (2010). Software survey: VOSviewer, a computer program for bibliometric mapping. Scientometrics, 84, 523-538.

Van Eck, N. J. \& Waltman, L. (2018). VOSviewer manual. Universitier Leiden.

Wei, F. \& Zhang, G. (2020). A document co-citation analysis method for investigating emerging trends and new developments: a case of twenty-four leading business journals. Information Research, 25(1).

Wheeler, G. S., Mc Kay, F., Vitorino, M. D., Manrique, V., Diaz, R., \& Overholt, W. A. (2016). Biological control of the invasive weed Schinus terebinthifolia (Brazilian Peppertree). Everglades Invasive Special. Southeastern Naturalist, 15(8), 15-34.

Williams, B. (2020). Dimensions \& VOSViewer bibliometrics in the reference interview. The Code4Lib Journal, 47, 1940-5758

Williams, D. A., Muchugu, E., Overholtz, W. A., \& Cuda, J. P. (2007). Colonization patterns of the invasive Brazilian Peppertree, Schinus terebinthifolius, in Florida. Heredity, 98, 284-293.

Williams, D. A., Overholt, W. A., Cuda, J. P., \& Hughes, C. R. (2005). Chloroplast and microsatellite DNA diversities reveal the introduction history of Brazilian Peppertree (Schinus terebinthifolius) in Florida. Molecular Ecology, 14 (12), 3643-3656.

Zotti-Sperotto, N. C., Ávila, M. B. R., Souza, R. A., Melo, E. C., Governicia, J. L., Gonzaga, D. A., Fonseca, M. C. M., Carneiro, A. P. S., Demuner, A. J, Pinheiro, P. F., \& Lisboa, C. F. (2021). Intermittent drying of Lippia origanoides H.B.K. leaves and Schinus terebinthifolius Raddi fruits. Industrial Crops \& Products, 161, 113152. 